\title{
The use of light-emitting diodes (LED) in commercial layer production
}

\section{mAuthor(s)}

Borille $\mathrm{R}^{1}$

Garcia $R^{2}$

Royer AFB ${ }^{1}$

Santana MR

Colet $\mathrm{S}^{1}$

Naas $I^{2}$

Caldara $\mathrm{FR}^{2}$

Almeida Paz $\mathrm{ICL}^{2}$

Rosa $\mathrm{ES}^{3}$

Castilho VAR ${ }^{3}$

M. Sc. student in Animal Science, FCA UFGD, Dourados, MS, Brazil

2 Professor, FCA - UFGD, Dourados, MS, Brazil

3 Undergraduate student, Animal Science, FCA - UFGD, Dourados, MS, Brazil

\section{Mail Adress}

*Corresponding author e-mail address

E-mail: borille.r@hotmail.com

\section{- Keywords}

Artificial lighting, commercial layers, egg weight, Haugh units.

\section{ABSTRACT}

Artificial lighting is one of the most powerful management tools available to commercial layer producers. Artificial light allows anticipating or delaying the beginning of lay, improving egg production, and optimizing feed efficiency. This study aimed at comparing the performance of commercial layers submitted to lighting using different LED colors or conventional incandescent lamps. The study was carried out in a layer house divided in isolated environments in order to prevent any influenced from the neighboring treatments. In total, 360 Isa Brown layers, with an initial age of 56 weeks, were used. The following light sources were used: blue LED, yellow LED, green LED, red LED, white LED, and $40 \mathrm{~W}$ incandescent light. Birds in all treatment were submitted to a 17-h continuous lighting program, and were fed a corn and soybean meal-based diet. A completely randomized experimental design with subplots was applied, with 24 treatments (six light sources and four periods) of three replicates. Egg production (\%) was significantly different $(p<0.05)$ among treatments, with the best results obtained with red LED, white LED, and incandescent light sources. Egg weight, feed intake, and internal egg quality (albumen height, specific gravity, and Haugh units) were not influenced ( $p>0.05$ ) by light source. It was concluded that the replacement of incandescent light bulbs by white and red LEDs does not cause any negative effect on the egg production of commercial layers.

\section{INTRODUCTION}

Lighting management is a very useful tool in egg production. The main factors to be considered are light source, wavelength and intensity, and photoperiod duration and distribution (Mendes et al., 2010).

Many of the physiological processes in poultry are influenced by light. Egg production and quality may be influenced by visible spectrum emitted by the light source, and some colors may be more stimulating than others (Nicholls et al., 1988). Each light bulb type used for artificial lighting in poultry houses has a different visible spectrum, but Etches (1996) found that poultry respond to most spectra commonly provided, independently of lamp type (fluorescent, incandescent, sodium vapor).

Spectral sensitivity curves of domestic poultry were determined by Prescott \& Whates (1999), using behavioral tests, and by Wortel et al. (1987), using an electro-physiological test. These researchers reported that poultry sensitivity is different from that of humans: poultry present broader sensitivity, perceiving ultraviolet A rays (UVA $320<8<400 \mathrm{~nm}$ ). According to Boni \& Paes (1999), broiler breeders produce more reproductive hormones when submitted to lighting with rays from the ends of the spectrum, such as purple and orange. 
Commonly used in artificial lighting systems in poultry houses, incandescent bulbs are one of the oldest artificial light sources and of the most frequently used around the world; however, they consume too much energy and produce a lot of heat.

The replacement of incandescent lamps by sodium lamps saves about 70\% electrical energy. Other practices may reduce energy consumption even further (Cotta, 2002), such as intermittent lighting programs applied in egg production or the use of new light sources available in the market, such as LED (light-emitting diode). This technology emits cold light and it is widely known for its high lighting efficiency and long life (Cervi, 2005). LED is a semiconductor device that emits spatially incoherent light at a relative narrow frequency spectrum generated by an electroluminescence effect. The color of the bulb depends on the composition and condition of the applied semiconductor material and may range from ultraviolet to infrared (Carvalho, 2007).

In addition of energy use, another important characteristic of poultry house lighting systems is the time of use of the lamps or lighting sources. LEDs may be used up to 50,000 hours, i.e., much longer than incandescent and compact fluorescent lamps, which life is 1,000 and 8,000 hours of use, respectively (Osram, 2007).

Some studies on the use of LED in poultry production showed that different light colors may influence some performance parameters; for instance, improvement of egg quality in commercial layers when using green LED (Er et al., 2007) and finisher performance in broilers using blue LED (Chen et al., 2007). All these advantages of the use of LED may contribute to reduce the maintenance cost of artificial lighting in layer houses while maintaining performance results.

Considering that different colors may influence egg production and quality, this study aimed at comparing the performance of commercial layers submitted to lighting using different LED colors or conventional incandescent lamps.

\section{MATERIALS AND METHODS}

This study was carried out at the experimental egg production sector of the School of Agricultural Sciences of the Federal University of Grande Dourados (FCA UFGD). A 112-d experimental period, divided in four periods of 28 days, was used. Birds were housed in an open poultry house in 36 conventional layer iron cages, equipped with trough feeders and nipple drinkers.
Plywood boards were used to divide the house so that each environment receiving artificial lighting from one light source was isolated from the others equipped with other light sources. Each environment included six cages with 10 birds each. A total number of 360 Isa Brown commercial layers, with initial and final ages of 56 and 72 weeks, were used.

The following light sources were used: blue LED, yellow LED, green LED, red LED, white LED (one $1 \mathrm{~W}$ LED lamp per cage) and a control environment (40W incandescent lamp), which was the lighting method previously used in that house. The lighting system was connected to a timer in order to supply a continuous lighting program of 17 hours/day (natural + artificial).

A corn and soybean meal-based diet was formulated according to the ingredient chemical composition and nutritional requirements of semi-heavy layers recommended by Rostagno et al. (2005). House temperature and relative humidity were monitored one daily using a digital hygro-thermometer placed at birds' height. Average temperatures of $22.2^{\circ} \mathrm{C} \pm 2.5$, $27.3^{\circ} \mathrm{C} \pm 4.1, \quad 29.5^{\circ} \mathrm{C} \pm 5.3$ and $25.9^{\circ} \mathrm{C} \pm 3.6$ were recorded during the four experimental periods, respectively.

Eggs were collected once daily and daily egg production was estimated and expressed as a percentage (\%). Average feed intake was measured, recorded, and expressed in $\mathrm{g} / \mathrm{bird} /$ day. On the last day of each experimental period, ten intact eggs were randomly collected from each replicate $(50 \%$ of the eggs produced on that day), identified, and weighed using a $0.01 \mathrm{~g}$-precision digital scale. Egg quality was analyzed as to specific gravity (1060 to $1100 \mathrm{~g} / \mathrm{cm}^{3}$ water) and albumen height by means of a digital pachymeter. Haugh unit was calculated as $\mathrm{UH}=100 \log \left(\mathrm{H}+7.57-1.7 \mathrm{EW}^{0.37}\right)$, where $\mathrm{H}$ is albumen height $(\mathrm{mm})$ and EW is egg weight, according to Haugh (1937).

A completely randomized experimental design with subplots was applied, with 24 treatments (six light sources and four periods) of three replicates of 20 birds per light source. Data were submitted to analysis of variance (ANOVA) using ASSISTAT (2011) software program, version 7.6 beta. Means were compared by the test of Tukey at $5 \%$ significance level.

\section{RESULTS AND DISCUSSION}

Light sources and periods significantly influenced $(p<0.05)$ layer performance (Table 1). The egg production (\%) of layers submitted to red LED, white 
LED and incandescent light were higher than that of the other treatments, being $4.83 \%, 5.55 \%$, and $5.17 \%$ higher that the egg production of layers under green LED lighting, which presented the lowest egg production. The egg production of layers in the blue LED and yellow LED environments was similar ( $p>0.05$ ), but lower $(p<0.05)$ compared with those submitted to red and white LED and to incandescent light.

Table 1 - Egg production/day (\%) of commercial layers submitted to artificial lighting using different LED colors and incandescent light.

\begin{tabular}{lccccc}
\hline Light & \multicolumn{5}{c}{ Period } \\
\cline { 2 - 6 } source & 1 & 2 & 3 & 4 & Mean \\
\hline 1-Blu & 91.66 & 88.02 & 90.62 & 86.25 & $89.14^{\mathrm{b}}$ \\
2-Yel & 89.16 & 88.75 & 89.58 & 89.37 & $89.21^{\mathrm{b}}$ \\
3-Gre & 86.97 & 86.87 & 88.33 & 85.20 & $86.84^{\mathrm{c}}$ \\
4-Red & 92.18 & 91.56 & 91.25 & 90.00 & $91.25^{\mathrm{a}}$ \\
5-Whi & 92.50 & 91.77 & 92.29 & 91.25 & $91.95^{\mathrm{a}}$ \\
6-Inc & 90.72 & 92.18 & 91.45 & 91.97 & $91.58^{\mathrm{a}}$ \\
\hline Mean & $90.53^{\mathrm{a}}$ & $89.86^{\mathrm{ab}}$ & $90.59^{\mathrm{a}}$ & $89.01^{\mathrm{b}}$ & \\
\hline
\end{tabular}

Means followed by the same letter are not statistically different by the test of Tukey at $5 \%$ probability level. coefficient of variation (\%) of periods $=4.11$ and light sources = 4.24. Light sources: 1-Blu = blue LED; 2-Yel = yellow LED; 3-Gre = greed LED; 4-Red $=$ red LED; 5-Whi $=$ white LED; and 6 -Inc = incandescent light.

According to Lewis \& Mori (2000), the penetration of the radiation of the red wavelength in the hypothalamus is more sexually stimulating that green or blue wavelengths. This may explain the better performance of the birds under the red LED, white LED and incandescent lamp, as their visible spectrum included red. According to Mendes et al. (2010), incandescent light present a red light aspect, whereas white fluorescent lights have a bluish aspect. The reason is that incandescent light produces longer wavelengths, close to red, whereas fluorescent lights produce shorter wavelengths, closer to green and blue. However, white is a homogenous mixture of all colors, including red, which may explain why the egg production of layers submitted to white LED light was similar to those in the incandescent lamp and red LED groups.

Spectral sensitivity curves of domestic poultry were determined by Prescott \& Whates (1999), using behavioral tests, and by Wortel et al. (1999), using an electrophysiological test. Those researchers observed that poultry curves were different from human curves, with a relatively wider sensitivity in poultry, which can also perceive ultraviolet A rays (UVA $320<8<400 \mathrm{~nm}$ ). However, Boni \& Paes (1999) found that broiler breeders are more responsive to light stimulus when submitted to lighting with rays from the ends of the spectrum, such as purple and orange, producing more reproductive hormones.

Some studies found that layers preferred spots lighted by compact fluorescent lamps than by incandescent lamps (Widowski et al., 1992), but showed no preference among compact fluorescent lamps with different frequencies (Widowski \& Duncan, 1996) or for high-intensity sodium lamps relative to low-intensity incandescent lamps (Vandenberg \& Widowski, 2000). It was also reported that insufficient light intensity reduced egg production (Ostrander \& Turner, 1962); however, Rocha (2008) observed that layer egg production increases when light intensity increases from 0.1 to 5 or 7 lux, but does not change at higher intensities. In general, high light intensities tend to stimulate bird activity.

Egg production per bird (\%) was significantly higher in the first three periods relative to the last. Egg production data were slightly higher the 88 and $81 \%$ egg production between 56 and 72 weeks of age mentioned in the genetic strain manual (ISA Hendrix Genetics Company 2011/12).

Feed intake (Table 2) was not significantly influenced by light sources or periods. This indicated that birds had the same visual sensitivity to all tested light sources, and did not change their feeding behavior as a function of light source. According to Etches (1996), the effect of lighting on feed intake is associated to birds' locomotion activity, which is very reduced during dark periods. As movement is reduced, so is energy expenditure, resulting in better feed efficiency and lower feed intake. Some authors (Rowland, 1987; Midgley et al. 1988) observed influence of lighting on feed intake only when artificial lighting programs were used, which is not the case of the present study.

Table 2 - Feed intake (g/hen/day) of commercial layers submitted to artificial lighting using different LED colors and incandescent light.

\begin{tabular}{lccccc}
\hline Light & \multicolumn{5}{c}{ Period } \\
\cline { 2 - 6 } source & 1 & 2 & 3 & 4 & Mean \\
\hline 1-Blu & 0.113 & 0.114 & 0.117 & 0.112 & $0.114^{\mathrm{a}}$ \\
\hline 2-Yel & 0.112 & 0.118 & 0.115 & 0.122 & $0.117^{\mathrm{a}}$ \\
3-Gre & 0.114 & 0.109 & 0.117 & 0.114 & $0.113^{\mathrm{a}}$ \\
\hline 4-Red & 0.114 & 0.113 & 0.116 & 0.117 & $0.115^{\mathrm{a}}$ \\
5-Whi & 0.117 & 0.112 & 0.116 & 0.117 & $0.116^{\mathrm{a}}$ \\
\hline 6-Inc & 0.113 & 0.113 & 0.117 & 0.116 & $0.115^{\mathrm{a}}$ \\
\hline Mean & $0.114^{\mathrm{a}}$ & $0.113^{\mathrm{a}}$ & $0.116^{\mathrm{a}}$ & $0.116^{\mathrm{a}}$ & \\
\hline
\end{tabular}

Means followed by the same letter are not statistically different by the test of Tukey at $5 \%$ probability level. coefficient of variation (\%) of periods $=5.70$ and light sources = 4.24. Light sources: $1-B l u=$ blue LED; 2 -Yel = yellow LED; 3-Gre = greed LED; 4-Red $=$ red LED; 5-Whi = white LED; and 6-Inc = incandescent light. 
Egg weight (Table 3) was not influenced either ( $p>0.05$ ) by light sources, but was significantly affected by evaluated periods, with the lowest weight obtained in the first period. Egg weight naturally increases as hens age. This was demonstrated in the present study: mean egg weight in periods 2 to 4 were similar, but $23.50 \%$ higher relative to period 1 .

Table 3 - Average egg weight $(\mathrm{g})$ of commercial layers submitted to artificial lighting using different LED colors and incandescent light.

\begin{tabular}{lccccc}
\hline \multirow{2}{*}{$\begin{array}{l}\text { Light } \\
\text { source }\end{array}$} & \multicolumn{5}{c}{ Period } \\
\cline { 2 - 6 } & 1 & 2 & 3 & 4 & Mean \\
\hline 1-Blu & 49.68 & 66.57 & 66.70 & 65.95 & $62.23^{\mathrm{a}}$ \\
2-Yel & 51.63 & 64.04 & 61.58 & 68.97 & $61.55^{\mathrm{a}}$ \\
3-Gre & 49.41 & 66.93 & 66.88 & 66.38 & $62.40^{\mathrm{a}}$ \\
4-Red & 53.25 & 66.81 & 68.87 & 67.30 & $63.07^{\mathrm{a}}$ \\
5-Whi & 53.25 & 66.51 & 67.65 & 67.16 & $63.64^{\mathrm{a}}$ \\
6-Inc & 52.87 & 64.71 & 70.50 & 67.13 & $63.80^{\mathrm{a}}$ \\
\hline Mean & $51.02^{\mathrm{b}}$ & $65.93^{\mathrm{a}}$ & $67.03^{\mathrm{a}}$ & $67.15^{\mathrm{a}}$ & \\
\hline
\end{tabular}

Means followed by the same letter are not statistically different by the test of Tukey at $5 \%$ probability level. Coefficient of variation (\%) of periods $=7.59$ and light sources = 7.21. Light sources: 1 -Blu = blue LED; 2 -Yel = yellow LED; 3-Gre = greed LED; 4-Red $=$ red LED; $5-$ Whi $=$ white $L E D ;$ and $6-\operatorname{Inc}=$ incandescent light.

The results of the present study are consistent with the finding of some studies that showed that artificial lighting programs did not affect egg weight (Freitas et al., 2010; Lewis et al., 1992; Morris et al., 1988; Sauveur \& Mongin, 1983). On the hand, in the experiment carried out in China by ER et al. (2007), who compared different LED colors with incandescent lamp and obtained heavier eggs $(p<0.05)$ when incandescent light was used compared with red LED. Rozenboim et al. (1998) did not find any effects of light color or intensity on egg weight, but suggest that further studies should be carried out to elucidate this. Egg weight usually depends on hen age and to nutritional factors. Eisen et al. (1962) had already mentioned that egg size increases as hens age.

Egg quality parameters (albumen height, egg specific gravity, and Haugh units) were not affected $(p>0.05)$ by light sources, only by periods $(p<0.05)$, as shown in Tables 4, 5, and 6.

According to Pascoal et al. (2008), egg quality is measured to describe fresh egg production differences due to genetic, environmental and nutritional factors to which hens are submitted. Silversides et al. (1993) suggested that albumen height is sufficient to evaluate the internal quality of fresh eggs, except when comparing different layer ages.

In the present experiment, periods significantly influenced albumen height (Table 4), but not light sources. Average albumen height in period 1 (8.39 $\mathrm{mm})$ and $2(7.81 \mathrm{~mm})$ was higher than in period 3 $(7.03 \mathrm{~mm})$, which was the worst result. However, this parameter was similar ( $p>0.05)$ between periods 2 and 4. Albumen height is commonly used to evaluate internal egg quality and, according to Silversides \& Budgell (2004), tends to decrease as hen age and storage time increase. However, it may also be reduced when environmental temperature increases. Average environmental temperature reached $29.5^{\circ} \mathrm{C}$, which was approximately $2^{\circ} \mathrm{C}$ higher than the average temperature recorded in period 2 . According to Rozenboim et al. (2007), commercial layers exposed to high environmental temperature manifest reproductive activity failure, with consequent egg quality loss.

Table 4 - Albumen height $(\mathrm{mm})$ of commercial layers submitted to artificial lighting using different LED colors and incandescent light.

\begin{tabular}{lccccc}
\hline Light & \multicolumn{5}{c}{ Period } \\
\cline { 2 - 6 } source & 1 & 2 & 3 & 4 & Mean \\
\hline 1-Blu & 8.25 & 7.44 & 7.69 & 7.30 & $7.67^{\mathrm{a}}$ \\
2-Yel & 8.13 & 7.70 & 6.88 & 7.28 & $7.50^{\mathrm{a}}$ \\
3-Gre & 8.27 & 8.13 & 6.63 & 8.18 & $7.80^{\mathrm{a}}$ \\
4-Red & 8.73 & 8.34 & 7.17 & 7.75 & $7.99^{\mathrm{a}}$ \\
5-Whi & 8.52 & 7.09 & 6.68 & 8.34 & $7.66^{\mathrm{a}}$ \\
6-Inc & 8.46 & 8.14 & 7.11 & 6.82 & $7.63^{\mathrm{a}}$ \\
\hline Mean & $8.39^{\mathrm{a}}$ & $7.81^{\mathrm{ab}}$ & $7.03^{\mathrm{c}}$ & $7.61^{\mathrm{bc}}$ & \\
\hline
\end{tabular}

Means followed by the same letter are not statistically different by the test of Tukey at $5 \%$ probability level. Coefficient of variation (\%) of periods $=18.81$ and light sources $=$ 19.86. Light sources: $1-B l u=$ blue LED; $2-$ Yel = yellow LED; $3-$ Gre = greed LED; 4-Red = red LED; 5-Whi = white LED; and 6-Inc = incandescent light.

Alleoni \& Antunes (2001) mention five quantitative methods to estimate the quality of open eggs related to the albumen, but the most commonly used to express albumen quality is the Haugh unit. In general,

Table 5 - Haugh units of commercial layers submitted to artificial lighting using different LED colors and incandescent light.

\begin{tabular}{lrrrrr}
\hline \multirow{2}{*}{$\begin{array}{l}\text { Light } \\
\text { source }\end{array}$} & \multicolumn{5}{c}{ Period } \\
\cline { 2 - 6 } 1-Blu & 88.49 & 84.53 & 80.39 & 84.81 & $84.55^{\mathrm{a}}$ \\
2-Yel & 89.41 & 87.37 & 85.33 & 81.07 & $85.80^{\mathrm{a}}$ \\
3-Gre & 88.99 & 84.28 & 88.26 & 84.69 & $86.55^{\mathrm{a}}$ \\
4-Red & 89.85 & 89.42 & 89.13 & 81.00 & $87.35^{\mathrm{a}}$ \\
5-Whi & 88.50 & 84.14 & 81.13 & 84.04 & $84.45^{\mathrm{a}}$ \\
6-Inc & 88.17 & 83.75 & 88.11 & 82.09 & $85.53^{\mathrm{a}}$ \\
\hline Mean & $88.90^{\mathrm{a}}$ & $85.58^{\mathrm{a}}$ & $85.39^{\mathrm{a}}$ & $82.95^{\mathrm{a}}$ & \\
\hline
\end{tabular}

Means followed by the same letter are not statistically different by the test of Tukey at $5 \%$ probability level. Coefficient of variation (\%) of periods $=10.42$ and light sources $=11.08$. Light sources: $1-B l u=$ blue LED; $2-$ Yel = yellow LED; $3-G r e=$ greed LED; 4-Red = red LED; 5-Whi = white LED; and 6-Inc = incandescent light. 
high Haugh unit values indicate better egg quality (Rodrigues, 1975). In the present experiment, this parameter was not affected by the evaluated light sources or periods (Table 5). Fry et al. (1981), Fletcher et al. (1983) and Belyavin (1988) mentioned that Haugh unit values decrease as birds age, but this was not observed here.

Egg specific gravity (Table 6) did not present any significant differences ( $p>0.05$ ) among light sources, but was influenced by period. Egg specific gravity was higher during periods 1 and $2(p<0.05)$ relative to 3 and 4 . This parameter is routinely used on farms to examine eggshell quality. It is based on the principle that eggshell density is twice as high as yolk and albumen density (Gewehr et al., 2012).

Table 6 - Egg specific gravity $\left(\mathrm{g} / \mathrm{cm}^{3}\right)$ of commercial layers submitted to artificial lighting using different LED colors and incandescent light.

\begin{tabular}{lccccc}
\hline Light & \multicolumn{5}{c}{ Period } \\
\cline { 2 - 6 } source & 1 & 2 & 3 & 4 & Mean \\
\hline 1-Blu & 1099.44 & 1093.33 & 1088.88 & 1090.00 & $1092.91^{\mathrm{a}}$ \\
2-Yel & 1096.11 & 1094.44 & 1091.11 & 1090.00 & $1092.91^{\mathrm{a}}$ \\
3-Gre & 1095.55 & 1095.55 & 1090.00 & 1090.00 & $1092.77^{\mathrm{a}}$ \\
4-Red & 1093.33 & 1094.44 & 1090.00 & 1090.00 & $1091.94^{\mathrm{a}}$ \\
5-Whi & 1095.55 & 1095.55 & 1091.11 & 1090.00 & $1093.05^{\mathrm{a}}$ \\
6-Inc & 1093.33 & 1098.88 & 1095.55 & 1088.88 & $1094.16^{\mathrm{a}}$ \\
\hline Mean & $1095.55^{\mathrm{a}}$ & $1095.37^{\mathrm{a}}$ & $1091.11^{\mathrm{b}}$ & $1089.81^{\mathrm{b}}$ & \\
\hline
\end{tabular}

Means followed by the same letter are not statistically different by the test of Tukey at $5 \%$ probability level. Coefficient of variation (\%) of periods $=0.45$ and light sources $=$ 0.45. Light sources: $1-B l u=$ blue LED; $2-$ Yel $=$ yellow LED; $3-$ Gre = greed LED; 4-Red $=$ red LED; 5-Whi $=$ white LED; and $6-\operatorname{Inc}=$ incandescent light.

Er et al. (2007) found that eggshell quality of commercial layer eggs was statistically affected by monochromatic red, green, and blue light compared with incandescent lamps. The authors found that eggshell index and thickness were significantly higher when green light was used relative to the other treatments, as well as eggshell strength $(p<0.01)$ when compared to the other treatments. The findings of the present study are not consistent with that results or those obtained by Freitas et al. (2010), thereby suggesting further studies on the effect of LED colors on egg quality.

\section{CONCLUSIONS}

Under the conditions of the present experiment it was concluded that the replacement of incandescent light bulbs by white and red LEDs does not cause any negative effect on the egg production of commercial layers. Egg weight and internal egg quality parameters were not negatively influenced by the replacement of incandescent lamps by LEDs of all evaluated colors.

\section{ACKNOWLEDGEMENTS}

The authors wish to thank Conselho Nacional de Desenvolvimento Científico e Tecnológico (CNPq) and Coordenação de Aperfeiçoamento Pessoal de Nível Superior (CAPES) for supporting this research study.

\section{REFERENCES}

Alleoni ACC, Antunes AJ. Unidade haugh como medida da qualidade de ovos de galinha armazenados sob refrigeração. Scientia Agricola 2001;58(4):681-685.

Assistat. Software. Versão 7.6 Beta [citado 2012 Jan 2]. Disponível em: http://www.assistat.com/indexp.html.

Belyavin CG. Egg quality as influenced by production systems. World's Poultry Science Journal 1988;44:65-67

Boni IJ,Paes AOS. Programa de luz para matrizes: machos e fêmeas. $2^{\circ}$ Simpósio Técnico sobre Matrizes de Frangos de Corte; 1999; Chapecó. Santa Catarina. Brasil.

Carvalho HMB. Diodos emissores de luz de alto brilho e alta potência [artigo DL-05]. São Carlos: Directlight; 2007.

Cotta JTB. Galinha: produção de ovos. Viçosa: Aprenda Fácil; 2002. 260p.

Cervi M. Semiconductor Lighting System Controlled Through a LIN Network to Automotive Application. Industry Applications Conference IAS; 2005

Chen Y, Cao J, Liu W, Wang Z, Xie D, Jia L. green and blue monochromatic lights promote growth and development of broilers via stimulating testosterone secretion and myofiber growth. Journal of Applied Poultry Research 2007;17(2):211-218.

Eisen EJ, Bohre BB, Mckean HE. The Haugh unit as a measure of egg albumen quality. Poultry Science 1962;41:1461-1468.

Etches RJ. Reproducción aviar. Zaragoza: Acribia; 1996. p.339.

Er D, Wang Z, Cao J, Chen Y. Effect of monochromatic light on the egg quality of laying hens. The Journal of Applied Poultry Research 2007;16(4):605-612.

Fletcher DL, Britton WM, Pesti GM, Rahn AP. The relationship of layer flock age and egg weight on egg component yields and solids content. Poultry Science 1983;62:1800-1805

Freitas HJ, Cotta JTB, Oliveira Al, Murgas LDS, Gewehr CE. Efeito de diferentes programas de iluminação para poedeiras semi-pesadas criadas em galpões abertos. Revista Biotemas 2010;23 (2):157-162.

Fry JL, Moore JS, O'steen AW. Strain difference and initial quality relationships to rate of interior egg quality decline. Poultry Science 1981;60:649-652

Gewehr CE, Oliveira V, Rosniecek M, Follmann DD, Cezaro AM. Programas de iluminação para poedeiras semi-pesadas. Biotemas 2012;25(1):151157.

Haugh RR. The Haugh unit for measuring egg quality. United States Egg Poultry Magazine 1937;43: 552-555. 


\section{layer production}

Isa Hendrix Genetics Company. General Management Guide 2011/12 [cited 2012 Maio 15]. Available from: http://www.isapoultry.com/en/ Products/ISA/ISA\%20Brown.aspx.

Lewis PD, Perry GC, Morris TR, Midgley MM. Intermittent lighting regimes and mortality rates in laying hens. World's Poultry Science Journal 1992;48:113-120.

Lewis PD, Morris TR. Poultry and coloured light. World's Poultry Science Journal 2000; 56:189-207.

Mendes AS, Reffati R, Restelatto R, Paixão SJ. Visão e iluminação na avicultura moderna. Revista Brasileira Agrociência 2010;16(1-4):5-13.

Midgley M, Morris TR, Butler EA. Experiment with the biomittent light system for laying hens. British Poultry Science 1988(29)2:333-342.

Morris TR. Use of intermitent light to save feed and to improve egg shell quality in laying flocks. 17 $7^{\text {th }}$ World's Poultry Congress; 1988; Nagoya. Japan. p. 161-164.

Nicholls TJ, Goldsmith AR, Dawson A. Photofractoriness in birds and comparison with mammals. Physiological Reviews 1988; 68(1):133176.

Ostrander CE, Turner CN. Effect of various intensities of light on egg production of single comb white leghorn pullets. Poultry Science $1962 ; 40: 1440$

Osram. Osram to Brazil, Website. [cited 2007 Set 30]. Available from: http://www.osram.com.br.

Pascoal LAF, Bento Junior FA, Santos WS, Silva RS, Dourado LRB, Bezerra APA. Qualidade de ovos comercializados em diferentes estabelecimentos na cidade de Imperatriz - MA. Revista Brasileira de Saúde e Produção Animal 2008;9(1):150-157.

Prescott NB, Wathes CM. Spectral sensitivity of the domestic fowl. British Poultry Science 1999; 40:332-339.

Rocha DCC. Características comportamentais de emas em cativeiro submetidas a diferentes fotoperíodos e diferentes relações macho:fêmea. In: BONI IJ, PAES AOS. Programas de luz para matrizes: machos e fêmeas [Tese]. Viçosa (MG): Universidade Federal de Viçosa; 2008

Rodrigues PC. Contribuição ao estudo da conversão de ovos de casca branca e vermelha. [Dissertação]. Escola Superior de Agricultura "Luiz de Queiroz", Universidade de São Paulo; 1975.

Rozenboim I, Tako E, Gal-Garber O, Proudman JA, and Uni Z. The effect of heat stress on ovarian function of laying hens. Poultry Science 2007:86:1760-1765.

Rozenboim I, Zilberman E, and Gvarzyahu G. New monochromatic light source for laying hens. Poultry Science 1998;77:1695-1698.

Rowland KW. Intermittent lighting for laying fowls: a review. World's Poultry Science Journal 1987; 41(1):5-20.

Sauveur B, Mongin P. Performance of layers reared and/or kept under different 6-hour light-dark cycles. British Poultry Science Journal $1983: 24: 405-416$

Silversides FG, and Budgell K. Education and Production: The Relationships Among Measures of Egg Albumen Height, $\mathrm{pH}$, and Whipping Volume. Poultry Science 2004;83(10):1619-1623.

Silversides FG, Twizeyimana F, Villeneuve P. Research note: a study relating to the validity of the Haugh unit correction for egg weight in fresh eggs. Poultry Science 1993;72(4):760-764

Vandenberg C, Widowski TM. Hen's preferences for high-intensity highpressure sodium or low-intensity incandescent lighting. Journal of Applied Poultry Research 2000;9:172-178.

Wortel JF, Rugenbrink H, Nuboer JFW. The photopic spectral sensitivity of the dorsal and ventral retinae of the chicken. Journal of Comparative Physiology 1987;160:151-154.

Widowski TM, Duncan IJH. Laying hens do not have apreference for highfrequency versus low-frequency compact fluorescent light sources. Journal of Animal Science 1996;76:177-181.

Widowski TM. The preferences of hens for compact fluorescent ove incandescent lighting. Journal of Animal Science 1992;72:203-211. 